\title{
WORK STATUS AS A PREDICTOR OF ACADEMIC PERFORMANCE IN THE FIELD OF DISTANCE HIGHER EDUCATION
}

\author{
JC WELMAN \\ Programme Group: Human Resource Management \\ Technikon Southern Africa
}

\begin{abstract}
This article reports on the academic success of 13590 Technikon SA students and the importance of their "work status" (employed/unemployed) in light of the co-operative education philosophy of technikons. The data was collected by means of the students' registration records, and analysed using a CHAID-analysis. The results indicated that the variable "work status" features second last on the list of nine successful variables for predicting academic performance. Generally, it would appear that the employment practice for technikon students is not as important a requirement for academic success as the co-operative education philosophy would like it to be.
\end{abstract}

\section{OPSOMMING}

Hierdie artikel lewer verslag oor die akademiese sukses van 13590 Technikon SA studente en die belangrikheid van hul "werkstatus" (werkend/werkloos) in die lig van die koöperatiewe onderwysfilosofie van technikons. Die inligting wat deur middel van die studente se registrasierekords ingesamel is, is ontleed met ' $\mathrm{CHAID-ontleding.} \mathrm{Die} \mathrm{resultate}$ toon dat die veranderlike "werkstatus" tweede laaste op die lys van nege veranderlikes voorkom wat akademiese verrigting voorspel. Oor die algemeen blyk dit dat die indiensnemingpraktyk van technikonstudente nie so 'n belangrike vereiste vir akademiese sukses is as wat die koöperatiewe onderwysfilosofie dit sou wou hê nie

Providers of study bursaries and loans need some indication of which applicants pose little academic risk, especially in view of the high attrition rate of, among others, distance higher education students (Fourie \& Van Zyl, 1998; Fraser \& Nieman, 1995; Jacobs, Fourie \& Smit, 1995). According to Collings (2000), predicting academic performance is also an important issue because educators envisage that black matriculants in particular will not find work and will be unprepared for entry to higher education institutions. The literature makes it clear that predicting academic performance is not simply a matter of investigating the cognitive abilities of potential students.

For example, in a study of psychosocial factors and academic performance among African women studying at a predominantly white university in South Africa, Malefo (2000) found that variation in students' academic performance could be attributed more to background variables than to cognitive factors. Similarly, in an investigation of the academic achievement of 452 educationally disadvantaged students, Van Rooyen (2001) found that "(t)ogether the biographical variables accounted for $30,49 \%$ ... of the variance in the bridging year ... All cognitive variables, however, could together only account for $4,44 \%$..." (p. 180).

Predicting academic success is crucial in a society where education is seen as the way to escape unemployment and the poverty that results from unemployment.

Möller (1992) reported on surveys that indicated that unemployed black people living in the townships of South Africa felt that education offered them an opportunity to become employed. Möller found that, compared with unemployed persons who are more highly qualified, unemployed persons whose qualifications are low feel that their chances of finding a job are less. There appear to be two groups of unemployed persons who experience a high level of risk in terms of education. The first group consists of individuals whose self-identities appear to present a risk. Such persons are mature and have a low standard of education. Individuals in the second group are generally young men. Their greatest frustration arises from boredom emanating from an inability to make a meaningful contribution to the community and so realise their potential.

Requests for copies should be addressed to: JC Welman, Programme Group: Human Resource Management, Technikom SA, Private Bag X6, Florida, 1710
Employers who hire such "qualified" persons need the assurance that these persons will prove cost-effective in terms of what their qualifications have to offer (Yorke, 1998). It seems that cooperative education may provide an answer to meeting the demand for such persons.

Perspectives on co-operative education

Co-operative education seems to be a philosophy which entails an educational strategy with the goal of integrating productive work experiences into the theoretical curriculum of an academic study field - a specific combination of work-based learning and academic study (Groenewald, Strümpfer \& Lessing, 2001). Although Herman Schneider, a 19th century teacher, may be regarded as the founder of the co-operative system of technological education, the idea of combining work with study was practised by mediaeval guilds with their apprenticeships. The earlier American training of lawyers for the bar and physicians for the practice of medicine also serves to illustrate the earlier application of co-operative education (Groenewald, 2002).

The goal of co-operative education is to equip students with the knowledge and skills necessary to attain occupational competence and economic independence. This goal relates to the learningreadiness of higher education students because, as Van Zyl and Lessing (1992) state, the determining question with learningreadiness is not merely why adults wish to learn, but rather their perceptions and expectations regarding what they will be able to do once they have undergone the learning experience.

Jacobs (1999) is of the opinion that one of the most important benefits of co-operative education is that it helps students understand the world of work through the integration of theory and practical work experience and the confirmation of a career path.

In terms of the co-operative education strategy of technikons, students are expected to engage in subject-relevant work in industry/commerce to gain practical experience (Welman, 2000). In this respect, graduation rates (rates of progress, dropout and completion), overall placement rates (employability) and career achievements by graduates are used as indicators in ascertaining whether the academic institution meets market expectations. Several studies shed some light on support for the use of such indicators. 
Williams, Sternberg, Rashotte and Wagner (1993) found that of 114 students in the USA (68 employed and 46 unemployed), the co-operative education students showed, within a five-month period, a significantly better practical working knowledge of the business world than non-co-operative education students.

These results are supported by a study conducted by the Peninsula Technikon on admission requirements, which led Booysen (1996) to make the following comment regarding the impact of students' work experience on their academic performance: "(S)tudents with previous work experience performed considerably better than those without these qualifications" (1996, p. 11).

In line with this, Welman and Basson (1995) investigated the relationship between the degree of subject-related work performed by 166 distance education students and their academic performance. Their study found that in comparison with older, male, Afrikaans- and English-speaking students, African-language speakers tended not to gain subject-related experience, experienced less job satisfaction and received lower marks for the third-year subject, Organisational Behaviour.

These results may be viewed in light of the following distance education model of Kember (1989).

The Kember model of student dropouts in distance education Most models used to investigate student attrition are, by nature, linear. A good example of such a model is that of Kember (Jacobs et al., 1995). According to Peterson (1993), this model aims to conduct a successful investigation into the rate of academic attrition among underprepared college students, and to reduce this rate by (timely) intervention.

Kember's model focuses on distance education and consists of seven main components that are bound in a linear fashion and form a cycle. According to Roberts, Boyton, Buete and Dawson (1991), who believe that the Kember model may be useful in investigating student attrition, these seven components can be reduced to five. This model is depicted in Figure 1 (components $1,2,3,4$ and 5) and is very briefly described in this article.

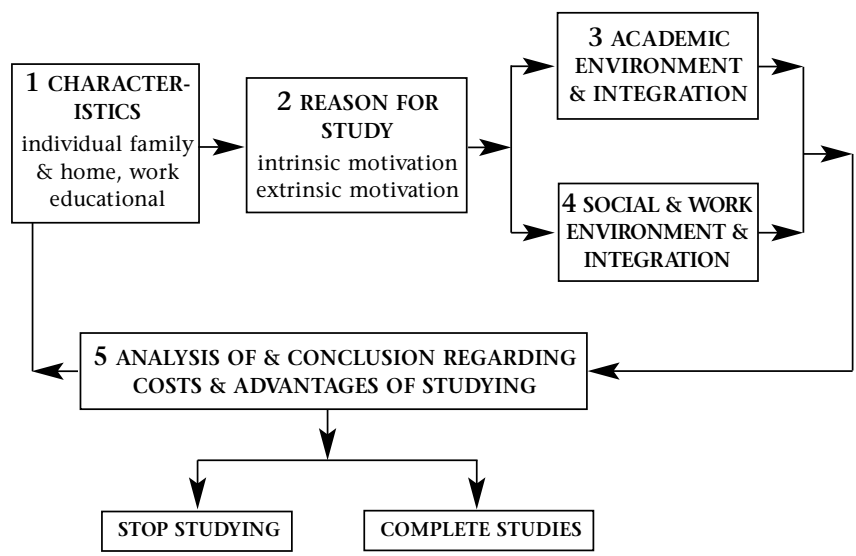

Figure 1: The Kember model of student drop-outs in distance education (adapted from Roberts et al., 1991, p. 55)

Figure 1 shows that a change in any of the five components has a direct effect on the other successive components. For example, not being able to afford the prescribed textbook (component 1 and/or 4 ) a student may deregister from the course only to reregister a year later once he/she has saved up enough money. This indicates the dynamic nature of a change in any of the variables of the five components of the model. A student studying via distance education, therefore, has to repeatedly analyse costs and advantages in line with changing circumstances, i.e. he/she has to reassess information.

Other than the characteristics of learners listed in component 1 of Figure 1, certain elements of components 2 and 4 of Kember's (1995) model may also apply to the present study.

\section{Component 2 of the Kember model}

Component 2 measures the extrinsic motivation of students. This type of motivation comprises the rewards a student might receive by obtaining the degree or other award. Many of these will be career-oriented, such as promotion, salary increases or increased opportunities to find better employment. (Kember, 1995)

In this light, and according to the overview of completed research provided by Gibson (1992), students' motivation to do well might be improved if they feel that the course they are studying relates to their career.

\section{Component 4 of the Kember model}

The social integration construct, which is fundamental to component 4, examines the degree to which students are able to integrate their academic study with other, often conflicting, employment, family and social requirements." (Kember, 1995)

In this regard Snelgar (1990) found that the high failure rate of part-time students in South Africa relates to stress at work and a high degree of role ambiguity (student versus worker). Also, if a student is employed full-time, his/her academic performance, in particular during test and examination times, may be adversely affected. Snelgar wrote that:

It is vital to empirically research variables which are likely to affect performance of part-time students, and potential 'buffers' of such variables, in order that students may develop constructive coping behaviours, and universities and organisations may play an active role in applying those buffers $(1990$, p. 46).

In summary, the Kember model is significant to the present study, because it demonstrates that the advantages that a course holds for a registered student must outweigh the costs so as to prevent the student from withdrawing from the course and registering with another educational institution. When a student expects that the successful completion of an academic course/qualification will lead to a career path, he/she may be externally motivated to complete it. On the other hand, the employed student may face several constraints that may hinder him/her to perform academically as well as he/she has the potential for.

\section{Problem statements and research questions}

It may be asked whether the high failure and dropout rates among students at distance higher education institutions may be attributed to the extent to which the unemployed/employed student's work experience affect his/her academic performance.

Because of the limitation that distance education places on the job placement role of a technikon such as Technikon SA (TSA), the onus is on students to make contact with (potential) employers. Although it is assumed that students are employed while studying towards a specific and specialised career, this is in fact not true of a third of TSA students. What, therefore, are the implications of co-operative education within a distance education environment such as TSA?

The social benefits to the South African community of investing in the development of a higher-level workforce (Johnston, 1993) should be high if job placement programmes are to succeed in improving academic performance and so, therefore, also TSA's potential student retention rate. The current investigation can perhaps help answer the question of whether the high failure and drop-out rates at distance higher education institutions can be attributed to the registered student's lack of work experience, and indeed whether such a disadvantageous position may possibly be rectified through the implementation of job placement programmes as part of co-operative education (SASCE Editorial, 2001).

\section{Aim of the study}

The aim of this article is to report on an investigation on whether work status, compared to other variables, does indeed play a crucial role in determining academic performance. A 
further aim is to explore and confirm the implications of cooperative education (as supported by the background information) on various perspectives in this regard.

\section{METHOD}

\section{Participants}

Initially, more than 27000 TSA first-year students studying various technikon subjects, ranging from Animal Studies to Financial Accounting and Human Resource Management, were involved. Of these, 13590 student records were used.

\section{Measuring instrument}

The following relevant variables, as detailed on TSA student registration forms and computer files, were investigated as predictors of distance-education readiness:

- Work status (i.e. employed/unemployed)

- Activity before registration (e.g. scholar, student at other institution, TSA student, labour force or other).

Procedure

The registration and academic performance records of 13590 Technikon SA students were researched over a period of four years. These were used to assign the students to one of the eight academic performance groups (criterion groups) shown in Table 1 with their respective percentages.

TABLE 1

ACADEMIC PERFORMANCE'S RELATION TO THE EIGHT CRITERION GROUPS

\begin{tabular}{llr}
\hline Codes & Academic performance groups & $\%$ \\
\hline 1(can) & Cancelled studies - no assignments submitted & 21,0 \\
2 (gup) & Submitted an insufficient no. of assignments & 13,5 \\
$3($ exm) & Did not earn 40\% to gain examination admission & 4,0 \\
$4($ not) & Gained examination admission but did not write & 7,0 \\
$5($ fal) & Failed the examination & 17,7 \\
6 (pas) & Passed the examination & 29,7 \\
7 (brg) & Students from groups 2-5 who repeated and passed & 1,8 \\
$8(2 x f)$ & Students from groups 2-5 who repeated and failed & 5,3 \\
\hline
\end{tabular}

Total $=13590$ students

Statistical analysis

A CHAID-analysis was performed. Figures known as dendrograms (branched diagrams showing relationships between variables) are used to illustrate the results of a CHAID-analysis and to show which explanatory variable (also referred to as a predictor variable) can be associated most strongly (from a statistical point of view) with the dependent variable (i.e. academic performance in the case of this investigation). Such explanatory variables, such as work status, thus distinguish the best between the criterion groups (academic performance groups). By way of a second branch a next variable, e.g. marital status, then illustrates the second-best explanatory variable on the dendrogram to distinguish between the criterion groups, etc.

A CHAID-analysis also helps to join/merge, statistically, the predictor variables into homogeneous groups (Pietersen \& Damianov, 1998), for example, the activity before registration at TSA as "technikon students" with "other students" in the present study. Even though the number of students in such a grouping may be large enough to justify the technique, groups of variables sometimes are no further branched by the CHAIDanalysis technique because this would, according to the computer program, be of little statistical value measured against the performance distribution of the criterion groups as explained by the other predictor variables.

\section{RESULTS}

Only the results of a study by Welman (2000) that relate to this investigation are shown. The purpose of the reported study was to identify first-time students in South Africa who are not ready to enrol formally with Technikon SA, and so to avoid a potentially high attrition rate by predicting which prospective students would benefit from support programmes.

The numerical and alpha codes presented in Table 1 for the respective academic performance groups are used in following tables and figures.

\section{Frequencies}

Frequencies, in the form of percentages, are used to illustrate the distribution of the 13590 students into the eight performance groups according to the two predictor variables.

According to the results given in Table 2, those (among the students who wrote examinations) who performed poorly academically, as seen against other levels of this variable, had been in matric (grade 12) the previous year. The other levels consist of TSA students who were busy with other activities, such as military training, before enrolling with Technikon SA. The group of students that performed academically the best was the group comprising previous-year TSA students, whereas the labour force level showed no significant pattern in respect of academic performance different from the averages.

TABLE 2

DisTRIBUTION (\%) IN THE EIGHT ACADEMIC PERFORMANCE GROUPS OF THE LEVELS OF ACTIVITIES OF 13590 LEARNERS BEFORE REGISTERING AT THE TSA AS STUDENTS

\begin{tabular}{lccccccccc}
\hline & & \multicolumn{7}{c}{ Academic performance group } \\
\cline { 3 - 10 } Activity & $\begin{array}{l}\text { Within } \\
\text { total\% }\end{array}$ & $\begin{array}{c}\mathbf{1} \\
\text { can }\end{array}$ & $\begin{array}{c}2 \\
\text { gup }\end{array}$ & $\begin{array}{c}\mathbf{3} \\
\text { exm }\end{array}$ & $\begin{array}{c}4 \\
\text { not }\end{array}$ & $\begin{array}{c}\mathbf{5} \\
\text { fal }\end{array}$ & $\begin{array}{c}6 \\
\text { pas }\end{array}$ & $\begin{array}{c}7 \\
\text { brg }\end{array}$ & $\begin{array}{c}\mathbf{8} \\
\mathbf{2 x f}\end{array}$ \\
\hline Technikon student & 9,5 & $\mathbf{1 2}$ & $\mathbf{9}$ & 4 & 6 & $\mathbf{2 3}$ & 34 & $\mathbf{4}$ & $\mathbf{8}$ \\
Other student & 2,6 & 17 & 12 & 5 & 7 & 18 & 34 & 1 & 6 \\
Matric learner & 4,9 & 18 & 14 & 7 & 6 & 29 & 19 & 2 & 5 \\
Military personnel & 2,6 & 22 & 15 & 2 & 9 & 17 & 29 & 2 & 4 \\
Labourforce & 49,8 & 22 & 14 & 3 & 7 & 15 & 32 & 2 & 5 \\
Other & 30,6 & 22 & 15 & 5 & 7 & 19 & 26 & 1 & 5 \\
TOTAL & 100,0 & & & & & & & & \\
AVERAGE \% SCORE & & 21 & 13 & 4 & 7 & 18 & 30 & 2 & 5 \\
\hline
\end{tabular}

\% Figures expressed in percentages and rounded off

The results in Table 3 show that there is no meaningful difference between the academic performance of participants in this study who are unemployed, and of those who are employed.

TABLE 3 Work STATUS OF 13590 STUdents' DIISTRIBUTION (\%)

IN THE EIGHT ACADEMIC PERFORMANCE GROUPS

\begin{tabular}{lcccccccccc}
\hline & & \multicolumn{7}{c}{ Academic performance group } \\
\cline { 3 - 10 } Activity & $\begin{array}{l}\text { Within } \\
\text { total\% }\end{array}$ & $\mathbf{1}$ & $\mathbf{2}$ & $\mathbf{3}$ & $\mathbf{4}$ & $\mathbf{5}$ & $\mathbf{6}$ & $\mathbf{7}$ & $\mathbf{8}$ \\
& 33,4 & 22 & 13 & 4 & 7 & 17 & 32 & 2 & 4 \\
\hline Unemployed & 66,6 & 20 & 14 & 4 & 7 & 18 & 29 & 2 & 6 \\
Employed & 100,0 & & & & & & & & \\
TOTAL & & 21 & 13 & 4 & 7 & 18 & 30 & 2 & 5 \\
AVERAGE \% SCORE & & 21 & not & fal & pas & brg & $\mathbf{2 x f}$ \\
\hline
\end{tabular}

$\%$ Figures expressed in percentages and rounded off. 
Cultural groups

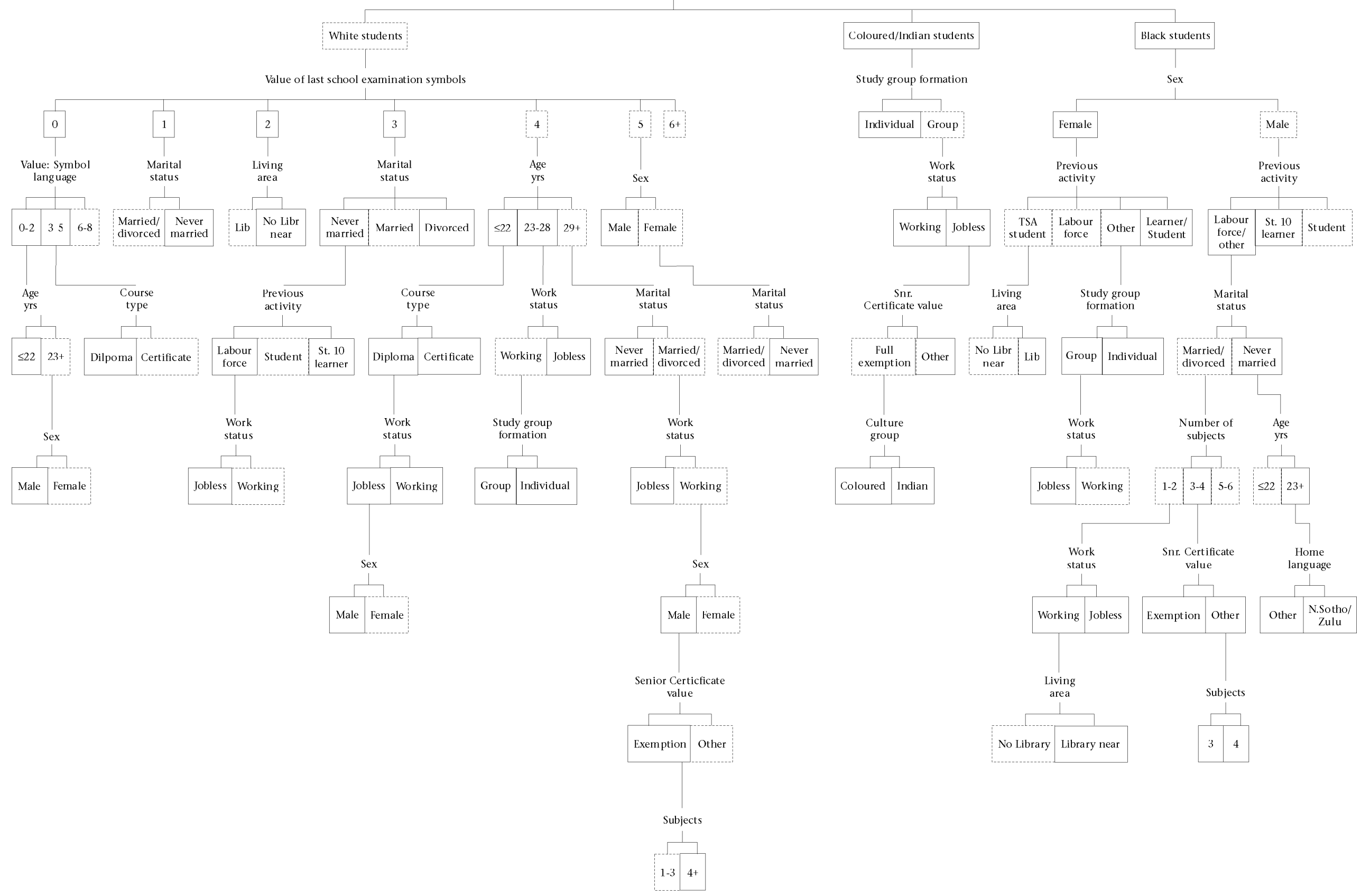




\section{CHAID-analysis}

The results of the original CHAID-analysis (Welman, 2000) show in Figure 2 the relative position of the variable "work status" in relation to the other variables used in the study.

Figure 2 shows that cultural grouping is the explanatory variable that is associated most strongly with (i.e. is statistically most significant) the dependent variable (i.e. academic performance). The following results will therefore be presented separately for white academic performance groups (Figure 3), coloured/Indian groups (which are grouped together by the analysis - Figure 4) and black African groups (Figure 5).

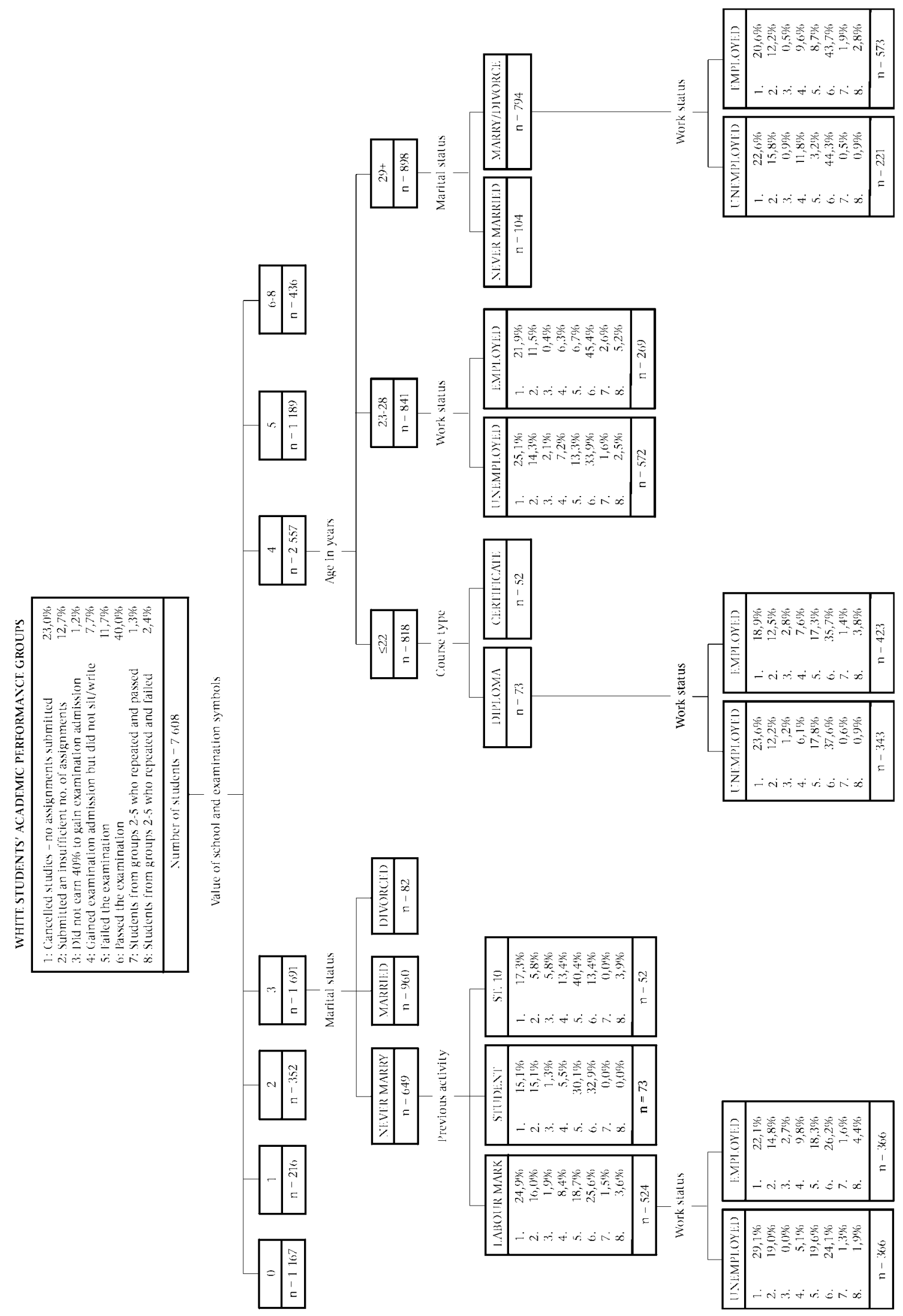

Figure 3: Dendogram of the white student groups.

(The values of school end examination symbols were calculated according to the Swedish formulae - see Louw, 1994.) 
BLACK STUDENTS' ACADEMIC PERFORMANCE GROUPS

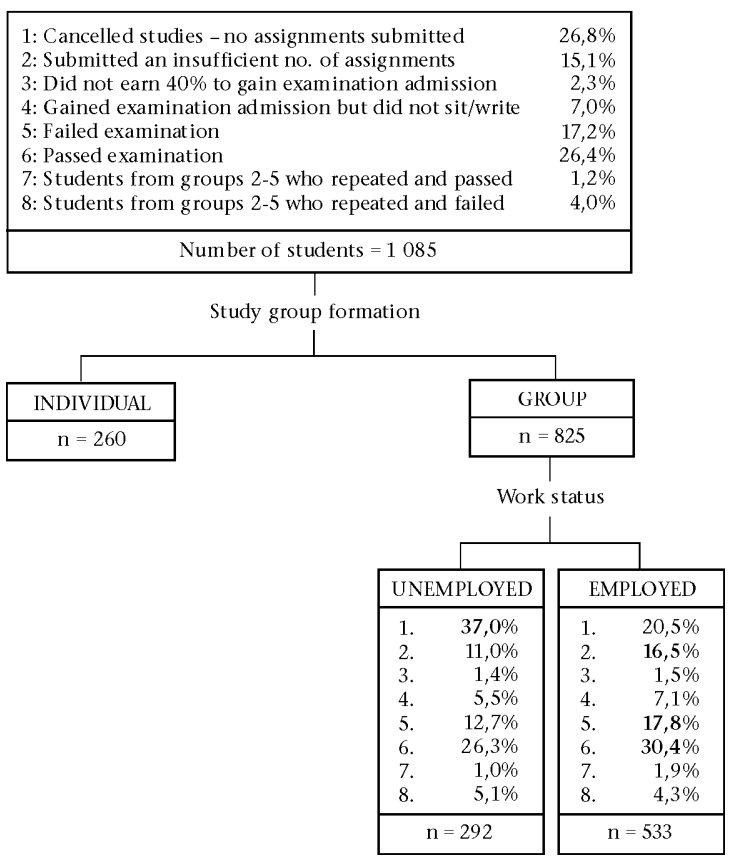

Work status includes the measurement levels "employed" and "unemployed". For the CHAID-analysis, this involves significantly large numbers for a variable in this investigation, particularly in the case of coloured/Indian students (1 085); white students who achieved final school examination values of 4 (2 557 students) and 3 (1 691 students) (where a value of 4 means better results than a value of 3 - see the Swedish formulae [Louw, 1994]); and 1808 black female and 3089 black male students.

The results in Figure 2 show that at least nine of the original 15 variables are able to distinguish between academic performance groups, and that the variable "work status" features second last on the list of nine successful variables for predicting academic performance. A comparison of Figures 3, 4 and 5 suggests that among white students, the variable "work status" played a less important role than did the other nine variables used in the study to predict academic success. It did, however, play a more meaningful role in the case of African (black, coloured and Indian) students.

Figure 4: Dendogram of the coloured/Indian students

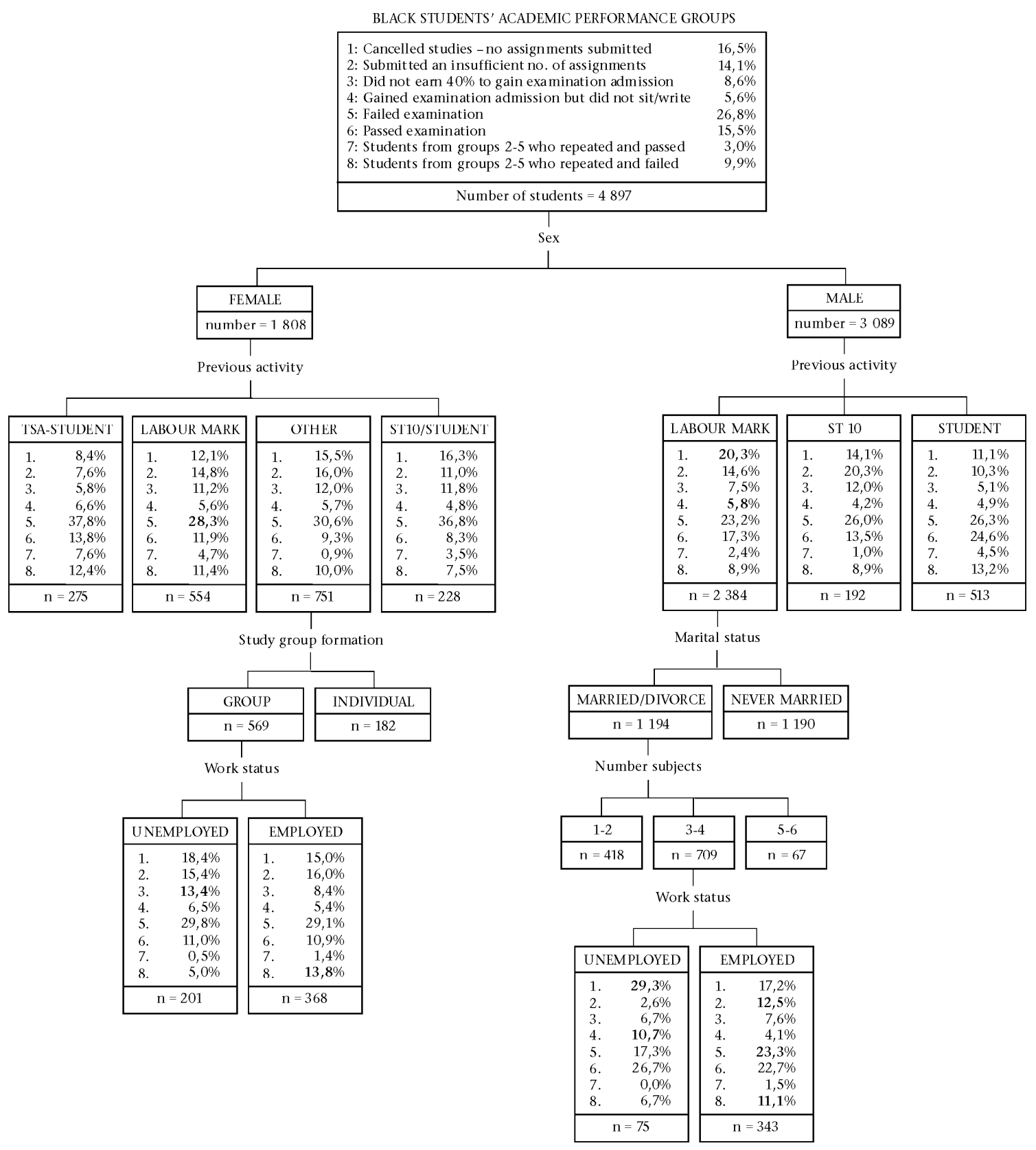




\section{DISCUSSION}

The most important findings to be discussed relate to the research question: "Can biographical characteristics such as a student's work status be used as a predictor of his/her future academic performance?".

The results indicated that of the original 15 variables at least nine are useful in distinguishing between academic performance groups and that the variable "work status" was second worst, of the nine successful variables, at predicting academic performance.

A phenomenon that seems to manifest itself in all cultural groups is that, in general (by taking all eight performance criterion groups into consideration), employed students seem to do slightly better than unemployed students.

Of significance when looking at Figures 3, 4 and 5 as a whole and by comparing them on the fifth to final (eighth) level nodes, is the repeated occurrence of work status as an explanatory variable (another five times - in addition to the previous two times). Figure 4 shows that work status at third-level node makes a distinction for only those coloured and Indian students who choose to form study groups. At the fourth-level node, the variables previous activity and work status are encountered only among the group of white students (Figure 3) and then at lower level nodes also for black African students (Figure 5).

Although the work status of Technikon students should be one of the most important variables, from the point of view of TSA's co-operative education policy, this does not appear to be true from the results of this investigation.

What students did before registering at TSA appears to be a good prediction variable of academic performance for all cultural groups, but those in the labour force do not seem to do particularly better or worse than those from other levels of this variable (being a student or a matric learner etc.).

In conclusion: There does not appear to be a strong relation between work experience and academic performance of students studying via distance education. The research results suggest that students with work experience and those without work experience and/or employment, perform academically almost equally well.

An important implication of the two variables that the research question/hypothesis address is that they cannot be used with confidence to predict the academic success of future TSA students. Consequently, they should not be used to identify those not ready for distance education. Even if industry and commerce employ students who have no previous work experience and tertiary institutions co-ordinate the placement of students in jobs, these initiatives may not necessarily have the anticipated positive influence on academic performance.

Generally, it would appear that the employment practice for technikon students is not as important a requirement for academic success as the co-operative education philosophy would like it to be. This could explain why the National Plan for Higher Education is "conspicuously quiet about the practice of co-operative education" (SASCE Editorial, 2001).

A quote from Kember (1995) summarises to some extent the spirit of the findings of this article:

(S)uccessful students are those who internalise responsibility for their own progress. These students negotiate with their families, work colleagues and friends to establish a time slot for study ... Those unable or unwilling to make sacrifices and negotiate a study sanctuary tend towards the negative track and attribute any unsuccessful outcomes to factors external to their control. (p. 219)

\section{Suggestions for further research}

Qualitative methods, such as conducting interviews with the students in order to determine the differences and similarities between types of student groups, should be used in future investigations (Coll \& Chapman, 2000). A scientific investigation needs to be conducted into the concepts of open learning and unlimited access to distance higher education in South Africa, where students often come from disadvantaged school backgrounds and are also unemployed. One of the topics for such an investigation would be how students' poor schooling and unemployment entail the further disadvantage of their being perceived as unsuitable for employment at a future time.

\section{REFERENCES}

Booysen, D. (1996). Admission criteria at Peninsula Technikon: A statistical investigation. Paradigms Journal for Staff Research and Debate at Peninsula Technikon, 3, 1-14.

Coll, R. K., \& Chapman, R. (2000). Choices of methodology for cooperative education researchers. Asia-Pacific Journal of Cooperative Education, 1 (1), 1-8.

Collings, J. (2000, January 28). Ministers must try harder. Financial Mail, 156 (4), (Education Africa Survey), 2-3.

Fourie, G. P., \& van Zyl, K. (1998). Perceptions of intrinsically and extrinsically motivated distance education students of the barriers to persistence. Journal of Industrial Psychology, 24 (2), 16-24.

Fraser, W. J., \& Nieman, M. M. (Eds.). (1995). The knowledge accessing modes, performance determinants and instructional preferences of first year students at eight major distance education institutions in South Africa. Pretoria: University of South Africa.

Gibson, C. C. (1992). Changing perception of learners and learning at a distance: A review of selected recent research. Proceedings of the second American symposium on Research in Distance Education, 4, 34-42.

Groenewald, T., Strümpfer, D., \& Lessing, B. (2001). Acceptance of co-operative education practice by the academic staff at Technikon Southern Africa. Journal of Industrial Psychology, 27 (3), 1-6.

Groenewald, T. (2002). 16 October 1946: 'Experimentia Docet' meaning experience teaches. Newsletter of the South African Society for Co-operative Education, 5 (2), 7-8.

Jacobs, H. (1999). Management of co-operative education in tertiary institutions. Newsletter of the South African Society for Co-operative Education, 2 (2), 8-10.

Jacobs, G. J., Fourie, C. M., \& Smit, H. M. (1995). Studenteslytasie binne afstandsonderwys [Student attrition in distance education]. RAU Bulletin vir Dosente, 27 (1), 2-8.

Johnston, R. (1993). The role of distance learning in professional development. Journal of the Institute of Management Services, 37 (4), 24-27.

Kember, D. (1995). Open learning courses for adults: A model of student progress. New Jersey: Educational Technology Publications.

Louw, A. (1994). Keuring van voornemende studente [Selection of prospective students]. South African Journal of Higher Education, 8 (1), 156-161.

Malefo, V. (2000). Psycho-social factors and academic performance among African woman students at a predominantly white university in South Africa. South African Journal of Psychology, 30 (4), 40-45.

Möller, V. (1992). Quality of life in unemployment: A survey evaluation of black township dwellers. Pretoria: HSRC Publishers.

Peterson, S. L. (1993). Career decision-making self-efficacy and institutional integration of underprepared college students. Research in Higher Education, 34 (6), 659-685.

Pietersen, J., \& Damianov, G. (1998). Guide to practical statistics. Pretoria: Human Sciences Research Council. 
Roberts, D., Boyton, B., Buete, S., \& Dawson, D. (1991). Applying Kember's linear-process model to distance education at Charles Sturt University-Riverina, Distance Education, 12 (1), 54-84.

SASCE Editorial. (2001). The National Plan for higher education and co-operative education. Newsletter of the South African Society for Co-operative Education, 4 (1), 1-3.

Snelgar, R. J. (1990). Stress and the part-time student: Work factors associated with failure rate. South African Journal of Psychology, 20 (1), 42-46.

Van Rooyen, E. (2001). Die voorspelling van die akademiese prestasie van studente in ' $\mathrm{n}$ universiteitsoorbruggingsprogram [The prediction of the academic achievement of students in a university's bridging programme]. South African Journal of Higher Education, 15 (1), 180-189.

Van Zyl, K. \& Lessing, B. C. (1992). Die meting van intrapersoonlike prosesse as determinant van leergereedheid by volwassenes in die werksituasie [The measurement of intra-personnal processes as a determinant of learning readiness of adults in the work situation]. Journal of Industrial Psychology, 18 (1), 7-12.

Welman, J. C. (2000). Die afstandsonderriggereedheid van technikonstudente [The distance education readiness of technikon students], Unpublished doctoral thesis, Rand Afrikaans University, Johannesburg.

Welman, J. C., \& Basson, P. A. (1995). The interrelationship between the work experience of distance education students, job satisfaction, and academic achievement. Journal of Industrial Psychology, 21 (1), 14-17.

Williams, W. M., Sternberg, R. J., Rashotte, C. A., \&

Wagner, R. K. (1993). Assessing the value of cooperative education. Journal of Cooperative Education, 28 (2), 32-55.

Yorke, M. (1998). Performance indicators relating to student development: can they be trusted?. Quality in Higher Education, 4 (1), 45-61. 